\title{
Çerikli Sulama Sahasında Toprak Tuzluluğunun Tahmininde Deterministik ve Stokastik Enterpolasyon Yöntemlerinin Kullanımı
}

\author{
Șeydagül ÖZDEMiR ${ }^{1, *} \quad$ Hikmet GÜNAL ${ }^{2} \quad$ Nurullah ACIR $^{3} \quad$ Hakan ARSLAN $^{4}$ \\ Kadir Aytaç ÖZAYDIN'1 Sultan Ergun KAHYAOĞLU' $\quad$ Aysel M. AĞAR5
}

\begin{abstract}
'T.C. Tarım ve Orman Bakanlığı, Tarla Bitkileri Merkez Araștırma Enstitüsü, Ankara
${ }^{2}$ Tokat Gaziosmanpașa Üniversitesi, Ziraat Fakültesi Toprak Bilimi ve Bitki Besleme Bölümü, Tokat

${ }^{3}$ Kırșehir Ahi Evran Üniversitesi, Ziraat Fakültesi Toprak Bilimi ve Bitki Besleme Bölümü, Kırșehir

${ }^{4}$ Ondokuz Mayıs Üniversitesi, Ziraat Fakültesi Tarımsal Yapılar ve Sulama Bölümü, Samsun

${ }^{5}$ Toprak Gübre ve Su Kaynakları Merkez Araștırma Enstitüsü, Ankara
\end{abstract}

\begin{abstract}
*Sorumlu yazar e-mail (Corresponding author e-mail):seydagul.ozdemir@tarimorman.gov.tr
Geliș tarihi (Received) : 13.12.2018

Kabul tarihi (Accepted): 04.03.2019

DOI : $10.21657 /$ topraksu.544699
\end{abstract}

\section{ÖZ}

Arazi kullanımlarının etkin bir șekilde planlanması ve yönetilmesi, bir bölgedeki toprakların özelliklerinin dağıımlarının doğru ve güvenilir enterpolasyon yöntemleri ile tahmin edilebilmesine bağıdır. Bu çalıșmada, Çerikli sulama sahasındaki toprakların tuzluluk, $\mathrm{pH}$ ve değișebilir sodyum yüzdesinin (ESP) mesafeye bağı değișkenliklerinin tahmininde ters uzaklık yöntemi (IDW) ve radyal tabanlı fonksiyon (RBF) gibi iki deterministik ve sıradan kriging (OK), evrensel kriging (UK) ve basit kriging (SK) gibi üç stokastik enterpolasyon yönteminin performansları karșılaștııımıștır. Çalıșma alanı, Yerköy'ün 8 km doğusundan bașlamakta ve Delice Çayı boyunca uzanarak Delice Çayının Kızılırmak Nehri ile birleștiği yere kadar devam etmektedir. Toplam 14924 ha olan çalıșma alanında 113 noktada 0-30, 30-60 ve $60-90 \mathrm{~cm}$ derinliklerden toprak örnekleri alınmıș ve elektriksel iletkenlik (EC), $\mathrm{pH}$ ve ESP belirlenmiștir. Çalıșma alanında toprakların EC değerleri 0-30, 30-60 ve 60-90 cm'de sırası ile 0.65 ile 67.1 dS m-1, 1.07 ile 98.80 ve 0.99 ile 54.50 dS m-1 arasında değișmiștir. Derinlik arttıkça ortalama tuzluluk değerlerinde de artıș olduğu görülmektedir. Bu durum, çalıșma alanında özellikle bazı lokasyonlarda toprak profilinin tamamında șiddetli tuzluluk sorununun olduğuna ișaret etmektedir. Hata kareleri toplamının karekökü (RMSE) ve ortalama mutlak hata (MAE) değerleri karșılaștıııldığında, deterministik yöntemlerden RBF-IM ve stokastik yöntemlerden SK'nın kendi gruplarındaki diğer yöntemlerden daha iyi performans ortaya koyduğu görülmüștür. Bu nedenle, mesafeye bağlı değișkenliğin haritalanması ișlemlerinde kullanılan programların öngörülen veya varsayılan (default) yöntemini kullanarak yapılan interpolasyonlarda önemli düzeyde hata olușabileceği düșünülmektedir. Bu nedenle, her bir özellik ve derinlik için yapılacak haritalamalarda birden fazla sayıda yöntem denenmeli ve en doğru sonucu veren interpolasyon yöntemi kullanılarak tahminler yapıımalı ve haritalar olușturulmalıdır.

Anahtar Sözcükler: Tuzluluk, mesafeye bağı değișkenlik, tahmin, jeoistatistik, basit kriging,

\section{Use of Deterministic and Stochastic Interpolation Methods for Estimating Soil Salinity in Çerikli Irrigation Area}

\section{Abstract}

Efficient planning and management of land uses relies on the ability to estimate the spatial distribution of soil characteristics in a region by accurate and reliable interpolation methods. In this study, the performances of two stochastic interpolation techniques such as inverse distance weighting 
(IDW) and radial basis function (RBF), and two deterministic methods of ordinary kriging (OK), universal kriging (UK) and simple kriging (SK) were compared to estimate the spatial variation of salinity, $\mathrm{pH}$ and exchangeable sodium percentage (ESP) of soils located in Çerikli Irrigation Area covering a total of 14924 ha land. The study area is located 8 km east of Yerköy in Yozgat province of Turkey and extends along the Delice Stream to the point where Delice Stream merges with Kızlırmak River. Soil samples of 0-30, 30-60 and 60-90 cm depths were taken from 113 locations in the study area. Electrical conductivity $(\mathrm{EC}), \mathrm{pH}$ and ESP of the samples were determined in the laboratory following the standard analysis procedure. The EC values of the soils ranged from 0.65 to 67.1 , from 1.07 to 98.80 and from 0.99 to $54.50 \mathrm{dS} \mathrm{m-1}$ at 0-30, 30-60 and 60-90 cm, respectively. The average salinity increased as the soil depth increased. The results indicated that some locations in the study area have severe salinity problems in the soil profile. Evaluations of root-mean-square error (RMSE) and mean absolute error (MAE) revealed that RBF-IM as deterministic and SK as stochastic interpolation method performed better estimation results compared to the other interpolation methods. Therefore, significant errors may occur in the interpolated values using the predicted or default method of the software's used in the mapping of spatial distributions. For this reason, more than one interpolation method should be achieved in mapping of each soil attribute obtained by depth, and therefore estimations and mapping should be achived by using the most accurate interpolation method.

Keywords: Salinity, spatial variability, spatial estimation, geostatistics, simple kriging,

\section{Giriș}

Toprakların kalitelerinin korunarak sürdürülebilir kullanımlarının sağlanması, tarımsal üretimin devamlılığı ve gıda güvenliği açısından son derece önemlidir. Sürdürülebilirlik, toprak amenajmanının doğru planlanmasına ve toprak sağığının (kalitesinin) düzenli takip edilmesine bağlıdır. Ancak, geniș alanlarda toprakların kalitesinin değișiminin belirlenmesi için çok sayıda toprak örneğinin alınması ve analiz edilmesinin gerekliiği, örneklenmeyen noktalarda toprak özelliklerinin doğru tahminini mümkün kılacak ara değer tahmin (enterpolasyon) yöntemlerinin belirlenmesini zorunlu kılmaktadır. Bu sayede daha az noktada yapılacak örnekleme ile geniș alanlarda sağlıklı bilgi üretmek ve buna bağlı olarak doğru planlama yaparak uygun amenajmanları belirlemek mümkün olacaktır. Buna ilaveten, geniș alanlarda toprağın sürdürülebilir kullanımını tehdit eden tuzluluk ve sodiklik gibi sorunların belirlenmesi ve gerekli tedbirlerin alınması da sağlanmıș olacaktır.

Kurak ve yarı-kurak iklim etkisindeki bölgelerde yetersiz drenaj altında bitkisel üretimi ve toprak organizmalarını etkileyecek düzeyde yüksek tuz içeren toprakların tanımlanması için kullanılan toprak tuzluluğu, sulamanın yapılmadığı arazilerde görülen kurak alan tuzluluğu (Juan vd. 2011 ) ve sulanan alanlarda görülen tuzluluk șeklinde iki grupta incelenmektedir (Cetin ve Kitda. 2003). Toprakta çözünebilir tuzların yüksek düzeyde birikimi; birincil ve ikincil minerallerin ayrıșması, yüksek düzeyde tuz içeren suların uygulanması, organik maddenin parçalanması ve taban suyundaki dalgalanmalar vb. nedenlere bağıdır. Bir arazinin tuzluluğa olan eğilimi, arazinin konumuna, topoğrafyasına, toprak tipine ve yağıș gibi faktörlere bağlıdır (Navarro vd., 2007). Arazideki toprak tuzluluğunun doğru bir șekilde haritalanması, sorunun giderilmesi ve amenajman için doğru kararların alınması așamasında son derece önemlidir (Budak ve Günal, 2015; Li vd., 2015).

Toprak özelliklerinin mesafeye bağlı değișkenliklerinin karakterize edilmesi ve toplanıp analiz edilecek örnek sayısının azaltılmasında mesafeye bağlı değișkenliği konu eden jeoistatistiksel yöntemler tarım biliminde etkin bir șekilde kullanılmaktadır (Cetin ve Kırda, 2003). Toprak özelliklerinin alansal tahminlerinin yapılmasında ters uzaklık yöntemi (IDW), (Cetin ve Diker, 2003; Emadi ve Baghernejad, 2014; Rahmanipour vd., 2014), ve radyal tabanlı fonksiyon (RBF) (Rahmanipour vd., 2014; Bhunia vd., 2018) gibi deterministik veya sıradan kriging (OK) (Cetin ve Kırda, 2003; Emadi ve Baghernejad, 2014; Bilgili, 2013), basit kriging (SK) (Surucu vd., 
2019; Nouri vd., 2018) veya evrensel kriging (UK) (Li vd., 2015) gibi stokastik enterpolasyon yöntemleri yaygın olarak kullanılmaktadır. Deterministik enterpolasyon teknikleri, benzerlik derecesine (IDW) veya düzgünleștirme derecesine (RBF) bağlı olarak matematiksel fonksiyonları kullanarak örnek noktalardan yüzeyler olușturur. Öte yandan, jeoistatistiksel enterpolasyon teknikleri (kriging), uzaysal bağımlılık yapısı olarak adlandırılan variogram modelini (Çetin, 1996) kullanır. Örnekleme noktaları arasındaki mesafeye bağlı yersel ya da mekânsal korelasyonu sayısallaștııı ve tahmin noktalarının çevresindeki örnekleme noktalarının uzaysal konfigürasyonunu tahminde dikkate alır (Isaaks and Srivastava, 1989).

Bu çalıșmanın amacı; Devlet Su İșlerinin (DSi) Kırıkkale Gelingüllü, Çerikli Sulaması Planlama, Revize, Arazi Sınıflama ve Planlama sahasında yer alan toprakların tuzluluk ve sodiklik durumlarının belirlenmesi, mesafeye bağlı korelasyonlarının modellenmesi, deterministik ve stokastik interpolasyon yöntemleri içerisinden en uygun tahmin yapan yöntemlerin seçilerek alansal dağılım haritalarının hazırlanmasıdır.

\section{MATERYAL VE YÖNTEM}

\section{Çalıșma Alanı ve İklimi}

Kırıkkale Gelingüllü Projesi Çerikli Sulama sahası içerisinde yer alan çalıșma alanı Yozgat-Yerköy'ün 8 km doğusundan bașlamakta, Delice çayı boyunca uzanarak çayın Kızıırmak'la birleștiği yere kadar devam etmektedir. Değinilen proje alanı toplam 14924 ha olmasına rağmen sulanabilir alan 12306 ha'dır. Genel olarak Delice çayı boyunca uzanan taban arazilerin yer aldığı çalıșma alanı $39^{\circ} 52^{\prime}-40^{\circ} 25^{\prime}$ kuzey enlemleri ve $34^{\circ} 00^{\prime}-34^{\circ} 10^{\prime}$ doğu boylamları arasında yer almaktadır (Șekil 1).

Çalıșma alanında, yazları sıcak ve kurak, kıșları yağıșlı ve soğuk geçen, tipik Orta Anadolu karasal iklimi görülmektedir. Çalıșma alanında yıllık ortalama yağıș 356 mm (Çiçekdağı) ile 571 mm (Yozgat) arasında değișmektedir.

\section{Toprak Örneklemesi ve Laboratuvar Analizleri}

Arazi kullanımı, noktalara olan ulașım kolaylığı, yükseklik, konumsal dağılım gibi parametreler coğrafi bilgi sistemleri içinde değerlendirilerek, 113 noktadan 0-30, 30-60 ve $60-90 \mathrm{~cm}$ derinliklerden toplam 339 adet bozulmuș toprak örneği alınmıștır. Toprak örneklerinin alındığı 113 noktanın coğrafi konumu hassas bir GPS ile kayıt edilmiștir. Toprak örnekleri, temiz ambalaj kağıtlarına serilerek, taș ve bitki parçacıkları ayıklanmıș ve havada kurumaya bırakılmıștır. Kuruyan topraklar tahta tokmaklarla dövülerek 2 mm'lik elekten geçirilmiș ve analizler için kutulara konularak etiketlenmiștir.

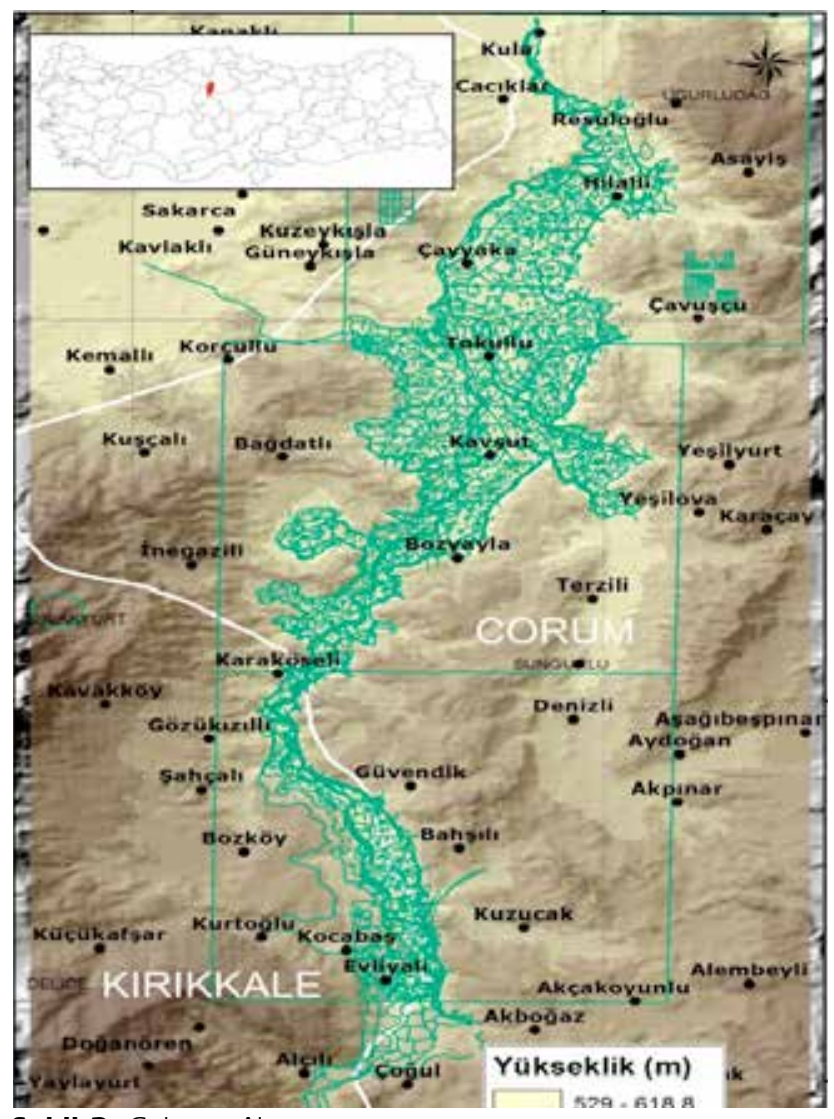

Șekil 2. Çalıșma Alanı

Figure 2. Study Area

Elektriksel iletkenlik ve pH ölçümleri hazırlanan saturasyon çamurunda Rhoades (1993)'in belirtilen yönteme göre yapılmıștır. Amonyum Asetat (1 N, pH=7.0) çözeltisi ile ekstrakte edilen süzükte kalsiyum, magnezyum, potasyum ve sodyum konsantrasyonları atomik absorpsiyon cihazında belirlenmiș ve değișebilir sodyum yüzdesi (ESP) değișebilir Na ve KDK değerlerinden, ESP = (Na/Katyon Değișim Kapasitesi) x 100 eșitliği ile hesaplanmıștır (Thomas, 1982).

\section{MesafeyeBağı̆Değișkenliğin Modellenmesi}

Mesafeye bağlı değișkenliklerin analizine geçmeden önce çalıșılan özelliklerin dağılımlarının normal dağılıma uyup uymadığı Webster (200 1 )'ın belirttiği șekilde çarpıklık katsayısı hesaplanarak kontrol edilmiștir. Webster (2001) toprak 
verilerinde normal dağılımdan ayrılmanın en önemli göstergesinin pozitif veya negatif çarpıklık değerleri olduğunu vurgulamıșlardır. Bu nedenle, bu çalıșmada da parametrelerin dağılımlarının șekli olarak tanımlanan çarpıkıı, normal dağılıma uygunluğun göstergesi olarak kabul edilmiștir. Webster (2001), çarpıklık değerleri -/+ 0.5 ile 0.0 aralığında değișim gösteren çarpıklık katsayıları için herhangi bir dönüșümü (transformasyon) gerek görmez iken, $-/+0.5$ ile $-/+1.0$ arasında değișen çarpıklık katsayısı olan değișkenler için karekök transformasyonunun yapılmasını önermișlerdir. Çarpıklık değeri -/+1.0'den yüksek olduğunda veride herhangi bir istatistiksel analiz yapmadan önce verinin logaritmik transformasyon yapılarak log-normal dağılıma uydurulması gerektiğini belirtmișlerdir. Toprak ve su kalitesi verilerinin çarpık dağılım göstermesi durumunda izlenmesi gereken yol ve uygulanacak yöntemin ayrıntıları Cetin ve ark. (1 999)'da bulunabilir. Her üç derinlikte belirlenen üç toprak özelliğinin de çalıșma alanı içerisinde normal dağılım göstermedikleri anlașılmaktadır (Çizelge 1). Bu nedenle verilerde mesafeye bağlı değișkenliklerin tanımlanması așamasına geçilmeden önce logaritmik dönüșüm uygulanarak verilerin log-normal dağılımla karakterize edilmeleri sağlanmıștır.

Farklı kriging yöntemlerine göre alansal dağılım haritalarının hazırlanmasından önce her bir toprak özelliği için deneysel yarıvariogram modelleri (Cetin ve Kirda, 2003) elde edilmiș ve en uygun teorik model ile bu modelin parametreleri belirlenmiștir. Her bir değișken için elde edilen yarı-variogram modelline ait kontrolsüz etki varyansı (Co), etki uzaklığı ve stokastik varyans (Sill ya da eșik değer, $\mathrm{CO}+\mathrm{C})$ değerleri, modelin uygunluğunu gösteren $r^{2}$ ve ölçüm hatalarından biri olan RSS (Azaltılmıș Kareler Toplamları) değerleri elde edilmiștir. Ayrıca örnekler arasındaki uzaklık sıfıra yaklaștıkça yarıvaryans değerinin sıfırdan uzaklașmasının önemli bir göstergesi olan "kontrolsüz etki varyansı oranı" değerleri (nugget/sill) hesaplanmıștır (Mulla ve McBratney, 2000; Citakoğlu ve ark., 2017).

\section{Enterpolasyon Yöntemleri}

Çalıșma alanında EC, ESP ve pH'nın alansal dağılımlarının haritalanmasında en doğru tahmin yapacak enterpolasyon yöntemini belirlemek için stokastik (jeoistatistik) yöntemlerden sıradan (ordinary) kriging (OK), basit (simple) kriging (SK) ve evrensel (universal) kriging (UK) yöntemleri ile deterministik yöntemlerden radyal tabanlı fonksiyon (RBF)'a ait beș farklı güç değeri ile ters mesafe ağırlıkı (IDW) enterpolasyon yöntemleri kullanılmıștır. Kriging enterpolasyon tekniği, minimum ortalama hata karesine sahip doğrusal optimum uygun bir enterpolasyon yöntemidir ve en iyi doğrusal yansız tahmin edici yöntemdir. Kriging yöntemi, gözlem verilerinin deneysel yarıvariogram yapısının belirlenmesi ve bu yapıya teorik yarı-variogram modelinin oturtulması ile bașlar ve bu jeoistatistik çalıșmalarının temelini olușturur. Kriging yöntemleri, Eșitlik 1'i kullanarak tahmin yapmaktadırlar (Webster ve Oliver, 2001).

$$
\hat{\mathrm{Z}}\left(\left(\mathrm{X}_{0}\right)-\mu=\sum_{\mathrm{i}=1}^{\mathrm{n}} \lambda \mathrm{i}\left[\mathrm{Z}\left(\mathrm{X}_{\mathrm{i}}\right)-\mu\left(\mathrm{X}_{0}\right)\right] \quad \text { Eșitlik } 1\right.
$$

Eșitlik 1'de; $\mu=$ Populasyonun beklenen değerini, $\lambda i=$ kriging ağırlık değerlerini, $n=$ tahmin yapmak için kullanılan örneklerin sayısını, Bu değer, arama penceresinin boyutuna bağlı olarak değișmektedir. $\mu\left(X_{0}\right)=$ arama penceresindeki örneklerin beklenen değeridir.

Basit kriging yönteminde esas kovaryans fonksiyonuna dayalı olarak alana dağılım ilkesine dayanmaktadır. Genel eșitliği kriging tahmin eșitliğinin modifikasyonu ile Eșitlik 2'de gösterildiği șekilde ifade edilir (Li ve Heap, 2008).

$$
\hat{\mathrm{Z}}\left(\mathrm{X}_{0}\right)=\lambda \mathrm{i} \sum_{\mathrm{i}=1}^{\mathrm{n}} \mathrm{Z}\left(\mathrm{X}_{\mathrm{i}}\right)+\left[1-\sum_{\mathrm{i}=1}^{\mathrm{n}} \lambda \mathrm{i}\right] \mu \quad \text { Eșitlik } 2
$$

Eșitlik 2'de, $\hat{Z}\left(X_{0}\right)$ : Tahmin edilen noktanın gerçek değeri, $\mu$ : Popülasyonun beklenen değeridir. Bu araștırmada $\mu$ parametresinin tüm alanda sabit olduğu kabul edilmiștir ve verilerin ortalaması kullanılmıștır. n: tahminde kullanılan örneklenen nokta sayısı ve $\lambda$ i: kriging ağırlık katsayılarıdır. Basit kriging, bu referans değerden artıkları tahmin etmek için kullanılır ve bu nedenle bazen "bilinen ortalamalı kriging” olarak adlandırılır (Wackernagel, 2003).

Sıradan kriging basit kriginge benzerdir. Tek fark sıradan kriging ișleminde Çetin ve Kirda (2003) ve Cetin (1996) tarafından da vurgulandığı üzere stasyonerlik șartı olan $\mu\left(X \_0\right)=\mu$ koșulunun sağlandığı varsayımı ve $\Sigma \lambda i=1$ koșulu altında Lagrange optimizasyonu kullanılarak kriging denklem sistemlerinin her tahmin yapılan nokta için çözülmesidir (Li ve Heap, 2008). 
Evrensel kriging, verinin güçlü bir eğilime (gidiș) sahip olduğu ve eğilimin basit fonksiyonlarla modellenebildiği durumlarda kullanılan bir yöntemdir. Bağımlı değișken, kriging için gerekli olan ikinci dereceden durağanlık kriterini karșılamadığında da Evrensel kriging kullanılmalıdır. İkinci dereceden durağanlık, ortalama ve varyansın tüm alanda aynı olduğu ve herhangi bir iki gözlem arasındaki korelasyonun sadece uzayda göreceli konumlara bağlı olduğu anlamına gelir (Kis, 2016). Belirli bir mesafede değișken değerlerinin sürekli artıș göstermemesi durumunda kalıntı yarı-variogramlar kullanılarak trendler giderilir ve kriging ile tahminler yapilır. Bu tür hesaplamalar Evrensel Kriging (UK) olarak bilinmektedir (Brus ve Heuvelink, 2007) ve Eșitlik 3 ile hesaplanır;

$$
\left.\hat{\mathrm{Z}}(S)=\sum_{\mathrm{i}=0}^{\mathrm{m}} \beta_{j} \mathrm{X}_{j}(\mathrm{~S})\right)+\varepsilon(\mathrm{S})
$$

Eșitlik 3

Eșitlikte: $\hat{Z}(S)=$ Tahmin edilmesi hedeflenen veriler, $X_{J} \mathrm{~S}=$ İki boyutlu konumsal koordinatlar, $(S)=$ Kovaryanslar, $\beta_{=}=$Regresyon katsayısı ve $\boldsymbol{\varepsilon}=$ Otokorelasyon sonucu kalıntıdır.

Enterpolasyon yöntemlerinde deterministik yöntemlerde sıklıkla kullanılmaktadır. Bu kapsamda Radial Basic Functions (RBF) ve ters uzaklık yöntem (IDW) yöntemleri kullanılmıștır. RBF metodu çok boyutlu verilerin interpolasyonunda kullanılan bir metottur. Genel olarak sınırlı sayıda ya da tahmin edilmesi zor olan noktaların tahmininde kullanılmaktadır. Bu metodun en büyük avantajı genel kısıtlamaların az olması nedeni ile herhangi bir boyutta rahatıkla kullanılmasıdır. Radyal Temelli Fonksiyon Eșitlik 4 ile hesaplanmaktadır (Wright, 2003).

$S(x)=\sum_{j=1}^{n} \lambda j \phi(\|\underline{x}-\underline{x j}\|)$

Eșitlik 4

Eșitlik 4'te: $x$ : Serbest değișken, $\{f j(j=1))$ : Eșitliğin cevap kümesi, $\quad S(x j)=f j, J=1, \ldots \ldots, n$ koșullarındaki genișleme kümesi, $\lambda j=$ genișleme katsayısı, $[A][\lambda]=$ [f] eșitlikteki, Aaj, $k=(\phi x-\|\underline{x}-\underline{x j}\|)$ radyal fonksiyon türlerini ve $\phi=$ tekli değișkeni ifade etmektedir.

IDW enterpolasyon tahminleri enterpolasyon Iokasyonundan belirli bir mesafe uzaklıktan gelen komșu noktaların ağırlık değerlerini dikkate alarak yapılmaktadır. Bu değerin hesaplanmasında ise uzaklıkların ters mesafe fonksiyonlarından yararlanılmaktadır. Bu varsayım değeri bilinen noktadan hedeflenen noktaya olan uzaklık arttıkça benzerliklerin azaldığı mantığına dayanmaktadır. IDW yönteminde enterpolasyon fonksiyonu Eșitlik 5'de gösterildiği șekilde hesaplanmaktadır.

$\lambda=\frac{1 / d i^{p}}{\sum_{j=1}^{n} 1 / d i^{p}}$ Eșitlik 5

Eșitlik 5 'de; $\lambda i$, enterpolasyon yapılan noktadaki tahmin edilen değer, $d_{i} x_{0}$ ve $x_{i}$ arasındaki mesafe, p, üs parametresi, $\mathrm{n}$ enterpolasyonda kullanılan örneklenen noktaların sayısıdır. IDW'nin doğruluğunu etkileyen ana faktör üs parametresinin değeridir. Mesafe arttıkça özellikle de üs parametresinin değeri arttığında, ağırlıklar azalır. Bu nedenle yakın örneklerin ağırlığı daha yüksektir ve tahmin üzerinde daha fazla etkiye sahiptir (Isaaks ve Srivastava, 1989). Her bir toprak özelliği için IDW yönteminde üs değeri 1.0'den 5.0'e kadar olacak șekilde 5 farklı üssel parametre değeri kullanılarak (IDW1, IDW2, IDW3, IDW4 ve IDW5) alansal dağılım haritaları olușturulmuștur. Elde edilen değerlere çapraz doğrulama yapıımıș ve en iyi sonucu veren güç değeri belirlenmiștir.

\section{Enterpolasyon Yöntemlerinin Karșılaștırılması}

Ölçülen değerler ve tahmin edilen değerler arasındaki ilișkiyi sorgulayabilmek, ölçülen değerlere en yakın sonucu veren bașka bir ifade ile yöntemler arasından en uygun olanının seçilmesinde literatürde farklı karșılaștırma yöntemlerinin dikkate alındığı görülmektedir. Genel anlamda ortalama hatakareleritoplamınınkarekökü (RMSE) veortalama mutlak hata (MAE) toprak verilerinde tahmin edilen ve gözlenen değerler arasındaki korelasyon değerlerinin kullanıldığı yaygın yöntemlerdendir (Emadi ve Baghernejad, 2014; Rahmanipour vd., 2014). Bu çalıșmada da enterpolasyonun doğruluğunu çapraz doğrulama ile tahmin etmede en uygun yöntemin seçilebilmesi için RMSE ve MAE birlikte kullanılmıștır. Enterpolasyon yöntemlerinin doğrulanması, çapraz doğrulama ișlemi ile değerlendirilmiștir. Çapraz doğrulamada veri seti içerisinden sırası ile bir noktayı atılır ve kalan noktalar kullanılarak bu konumun değeri hesaplanır. Çıkarılan noktanın konumundaki tahmin edilen ve ölçülen değerler karșılaștırılır ve bu ișlem, ikinci bir nokta için tekrar edilir. Tahmine dayalı bir modelin davranıșını doğru bir șekilde tahmin etmek için, çapraz doğrulama ișleminde, veriler modellerin olușturulması ve doğrulanması için kullanılan iki 
bölüme ayırılarak farklı variogramlar karșılaștırmıștır (Robinson ve Metternicht, 2006). Öncelikle her bir yöntem için en düșük RMSE değerini veren yari-variogramlar belirlenmiș ve en düșük RMSE değerini veren yöntem, en uygun yöntem olarak değerlendirilmiștir (Bilgili 2013).

\section{BULGULAR VE TARTIȘMA}

\section{Tanımlayıcı İstatistikler}

Her üç derinlik için belirlenen elektriksel iletkenlik (EC), değișebilir sodyum yüzdesi (ESP) ve $\mathrm{pH}$ değerleri Çizelge 1'de verilmiștir. Elektriksel iletkenlik değerleri ilk $30 \mathrm{~cm}$ derinlikte 0.45 ile $65.60 \mathrm{dS} \mathrm{m}{ }^{-1}$ arasındadır ve ortalama EC $5.25 \mathrm{dS} \mathrm{m}^{-1}$ dir. Enyüksek EC değeri, çalıșma alanında bazı yerlerin çok șiddetli tuzluluk etkisi altında olduğunu göstermektedir.

Toprak örneklemeleri bölgedeki hasat döneminden sonra yapılmıștır. Özellikle tahıl ekili alanlarda, hasat sonrası çıplak kalan arazi yüzeyinde șiddetli buharlașmanın etkisi ile tuzların yüzeye doğru hareket ettiği görülmüștür. Jorenush ve Sepaskhah (2003), sığ taban suyunun bulunduğu ișlenen tarım arazilerinin \%30'unda kapillar yükselme nedeni ile tuzluluk sorununun olduğunu bildirmișlerdir. Sulama yapılan alanlarda veya yağıșların yoğun olduğu bölgelerde toprağa giren su tuzluluğa neden olan iyonların profilin alt kısımlarına doğru hareket etmesine neden olurken, yağıșın ve sulamanın olmadığı dönemlerde taban suyu kapillar güçler ile yukarıya doğru hareket etmektedir. Yukarıya tașınan su, bitkiler tarafından tüketilmekte veya yüzeyden buharlașmaktadır. Bu durumda, yüzeyde veya kök bölgesinde tuzlar zamanla birikerek zarar verecek düzeylere kadar yükselebilmektedir.

Yüzeyin hemen altında yer alan 30-60 cm derinlikteki toprakların EC değeri ise 0.29 dS $\mathrm{m}^{-1}$ ile $55.40 \mathrm{dS} \mathrm{m}^{-1}$ arasında değișim göstermiș ve ortalama tuzluluk 5.26 dS $\mathrm{m}-1$ olarak hesaplanmıștır. $60-90 \mathrm{~cm}$ toprak derinliğindeki EC değerleri ise $0.37 \mathrm{dS} \mathrm{m}^{-1}$ ile $62.40 \mathrm{dS} \mathrm{m}^{-1}$ arasında değișim göstermiș ve ortalama EC değeri 6.09 dS $\mathrm{m}^{-1}$ olarak belirlenmiștir (Çizelge 1). Calıșma alanında derinlik arttıkça ortalama EC değerlerinin arttığı görülmektedir.

Arazi içerisinde herhangi bir özelliğin değișkenliğinin boyutunun belirlenmesinde varyasyon katsayısı (CV) değerleri yaygın bir șekilde kullanılmaktadır. Varyasyon katsayısının \%15'den küçük olması durumunda az değișken, \%15 ile \%35 arasında olması durumunda orta değișken ve \%35'den büyük olmasında ise çok değișken olarak değerlendirilmektedir (Wilding, 1985). Buna göre tüm toprak katmanlarındaki tuzluluk arazide büyük oranda değișkenlik göstermektedir. Cetin ve Kirda (2003) tarafından da belirtildiği gibi, toprak tuzluluğundaki bu davranıs normal ve beklenen bir durumdur. Dolasıyla tarla ölçeğinde dahi büyük değișkenlik gösterebilen tuzluğun arazideki değișkenliğinin yüksek olması beklenen bir bulgudur ve farklı bölgelerde rapor edilen CV değerleri ile de uyumludur (Emadi ve Baghernejad, 2014). Toprakların $\mathrm{pH}$ değerleri incelendiğinde 0-30 $\mathrm{cm}$ toprak katmanında 6.40 ile $8.40,30-60 \mathrm{~cm}$ toprak derinliğinde 6.84 ile 8.85 ve $60-90 \mathrm{~cm}$ toprak derinliğinde ise 6.66 ile 8.69 arasında değișim göstermiștir. Ortalama $\mathrm{pH}$ değerleri incelendiğinde ise toprağın alt derinliğine doğru $\mathrm{pH}$ değerlerinde azalıș olduğu görülmektedir. Değișim katsayıları tüm katmanlarda \%15'den küçük olduğunda $\mathrm{pH}$ değerlerindeki değișimin çok düșük seviyelerde olduğu belirlenmiștir.

ESP değerinin \%15 den büyük olduğu topraklar sodiklik açısından problem olduğunu

Çizelge 1. Temel tanımlayıcı istatistikler

Table 1. Basic Descriptive Statistics

\begin{tabular}{c|lcccccc}
\hline Toprak Özellikleri & En Küçük & En Yüksek & Ortalama & SD & CV & Carpıklık \\
\hline \multirow{3}{*}{$0-30 \mathrm{~cm}$} & EC dSm & 0.45 & 65.60 & 5.25 & 12.05 & 229.52 & 23.04 \\
& PH & 6.40 & 8.40 & 7.93 & 0.47 & 5.93 & -0.79 \\
& ESP \% & 0.18 & 52.76 & 7.36 & 8.17 & 111.05 & 14.57 \\
\hline \multirow{3}{*}{$30-60 \mathrm{~cm}$} & EC dSm & 0.29 & 55.40 & 5.26 & 9.72 & 184.79 & 16.24 \\
& PH & 6.84 & 8.85 & 7.85 & 0.48 & 6.11 & -0.90 \\
& ESP \% & 0.08 & 60.63 & 8.72 & 9.22 & 105.74 & 13.06 \\
\hline \multirow{5}{*}{$60-90 \mathrm{~cm}$} & EC dSm & 0.37 & 62.40 & 6.09 & 10.04 & 164.86 & 10.44 \\
& PH & 6.66 & 8.69 & 7.81 & 0.47 & 6.02 & -0.70 \\
& ESP \% & 0.14 & 55.70 & 11.26 & 10.78 & 95.74 & 6.39 \\
\hline
\end{tabular}

S.D: Standart Sapma; CV: Varyasyon Katsayısı (\%) 
göstermektedir. 0-30 cm toprak derinliğinde ESP değerleri \%0.18 ile \%52.76, 30-60 cm toprak derinliğinde $\% 0.18$ ile $\% 60.63$ ve $60-90 \mathrm{~cm}$ toprak derinliğinde ise ESP değerleri \%0.14 ile \%55.70 arasında değișim göstermiștir. Alandaki ortalama ESP değeri ise derinliklere göre \%7.36 ile \%11.26 arasında değișim göstermiș ve derinlik arttıkça ESP değerinin arttığı belirlenmiștir.

\section{Mesafeye Bağlı Değișkenliğin Modellenmesi ve Haritalama İșlemleri}

Çalıșılan özelliklerin mesafeye bağlı korelasyonları normal dağılıma dönüștürülen verilerde yarı-varyogramlar kullanılarak belirlenmiștir. Çalıșma alanında $\mathrm{EC}, \mathrm{pH}$ ve ESP'nin her üç derinlikteki mesafeye bağlı değișkenliklerinin belirlenmesinde elde edilen en uygun modeller ve bu modellere ait parametreler Çizelge 2'de verilmiștir. Tüm derinliklerde EC ve ESP için en uygun yarı-variogram modeli küresel iken $\mathrm{pH}$ değerleri için 0-30 cm'de küresel ve 3060 ve $60-90 \mathrm{~cm}$ için ise üssel modelin uygun olduğu belirlenmiștir. Kontrolsuz etki varyansının toplam varyansa oranı uzaysal bağımlıığın kısa mesafelerdeki bozunmasının ortaya konulmasında iyi bir göstergedir. Cetin ve Kirda, 2003). Bu oranın $\leq \% 25$ olması değișkenin kuvvetli uzaysal bağımlı, $\% 25$ ile \%75 arasında olması orta derecede uzaysal bağımlı ve $\% 75^{\prime}$ den fazla olması ise zayıf uzaysal bağımlı olarak sınıflandırımasına neden olmaktadır (Cambardella vd., 1994). Çalıșma alanında EC orta düzeyde (sırası ile \%37.5, \%29.7 ve \%30.3) mesafeye bağımlıık göstermektedir. Bununla birlikte $\mathrm{pH}$ değerlerinin ise her üç derinlikte de \%25'den daha düșük olduğu ve kuvvetli uzaysal bağımlı olduğu belirlenmiștir. ESP değerlerinin ise 0-30 ve 30-60 cm derinlikler için orta derecede bağımlı (\% 45.2 ve \% 25.3) ve 60$90 \mathrm{~cm}$ için ise kuvvetli uzaysal bağımlı (\%20.3) olduğu anlașıımıștır. Uzaysal bağımlılığın yüksek olması, değerlerin mesafeye bağlı olarak düzenli bir azalıș gösterdiğine yani uzaysal yapılarının olduğuna ișaret etmektedir.

Etki uzaklığı en yüksek toprak özelliğinin her üç derinlik için de EC olduğu görülmektedir. EC için belirlenen etki mesafeleri 0-30, 30-60 ve $60-90 \mathrm{~cm}$ için sırası ile $8150 \mathrm{~m}, 6850 \mathrm{~m}$ ve $6610 \mathrm{~m}$ 'dir. Bununla birlikte $\mathrm{pH}$ 'nın her üç derinlikteki etki değerinin de EC ve ESP'den daha kısa olduğu anlașılmaktadır. Kontrolsüz etki varyansı ölçüm yapılan en kısa mesafeden daha kısa mesafelerdeki değișkenlik tavrı ile ilgilidir. (Webster ve Oliver, 2001). Her üç derinlikte de en düșük kontrolsüz etki varyansına sahip özellik pH olmuștur (Çizelge 2). Kontrolsüz etki varyansının toplam varyans içerisindeki oranının büyük olması uzaysal bağımlııı yapısının mesafeye bağı değișkenliği yeterince karakterize edemediğini ve bu özelliklerde belirsizliği ortadan kaldırabilmek için daha kısa mesafelerde ve daha fazla sayıda örnek alınması gerektiği bildirilmiștir (Emadi ve Baghernejad, 2014). Bir diğer ifade ile, Çetin ve ark. (2001) tarafindan da açıkça belirtildiği gibi, kontrolsüz etki varyansının toplam varyans içerisindeki oranı arttıkça incelenen değișkenin daha çok rastgele karakterli olduğu ve uzaklığa bağlı bir bağımlııktan bahsetme olanağının olmadığı söylenebilir.

\section{Enterpolasyon Yöntemlerinin Karșılaștırılması}

Elektriksel iletkenlik değerlerinin alansal dağılımları

Tüm deterministik enterpolasyon yöntemleri karșılaștırıldığında örnekleme yapılan her üç toprak

Çizelge 2. Toprak özelliklerine ait uzaysal analiz sonuçları

Table 2. Results for Spatial Analyses of Soil Characteristics

\begin{tabular}{c|c|lcccccc}
\multicolumn{2}{c|}{ Toprak Özellikleri } & Model & $\begin{array}{c}\text { Kontrolsüz } \\
\text { Etki Varyansı } \\
(\text { Co) }\end{array}$ & Sill (Co+C) & $\begin{array}{c}\text { Etki uzak- } \\
\text { lığı (m) }\end{array}$ & $\begin{array}{c}\text { Kontrolsüz etki } \\
\text { varyansı oranı (\%) }\end{array}$ & $R^{2}$ & RSS \\
\hline \multirow{3}{*}{$0-30 \mathrm{~cm}$} & EC & Küresel & 0.363 & 0.967 & 8150 & 37.5 & 0.788 & 0.0636 \\
& PH & Üssel & 0.0317 & 0.207 & 2970 & 15.3 & 0.516 & 0.0026 \\
& ESP & Küresel & 0.484 & 1.07 & 7520 & 45.2 & 0.459 & 0.238 \\
\hline \multirow{3}{*}{$30-60 \mathrm{~cm}$} & EC & Küresel & 0.337 & 1.136 & 6850 & 29.7 & 0.732 & 0.126 \\
& PH & Üssel & 0.0225 & 0.219 & 2670 & 10.3 & 0.645 & 0.001 \\
& ESP & Küresel & 0.227 & 0.898 & 5510 & 25.3 & 0.437 & 0.231 \\
\hline \multirow{3}{*}{$60-90 \mathrm{~cm}$} & EC & Küresel & 0.379 & 1.252 & 6610 & 30.3 & 0.622 & 0.239 \\
& PH & Küresel & 0.0185 & 0.190 & 2670 & 9.7 & 0.621 & 0.00184 \\
& ESP & Küresel & 0.237 & 1.166 & 4470 & 20.3 & 0.554 & 0.206 \\
\hline
\end{tabular}


derinliğindeki EC değerlerinin alansal dağılımları için en düșükRMSE değeriniverentersuzaklıkyönteminin ağırlıküssü 1 olanının (IDW-1) en doğru sonuç verdiği görülmüștür. IDW yönteminde ağırlık gücünün artıșı ile RMSE değerinin arttığı görülmektedir. Stokastik enterpolasyon yöntemlerinin karșılaștırılmasında ise 0-30 cm derinlikteki toprakların EC değerlerinin alansal dağılımında UK ve OK yöntemlerinin her ikisinin de uygun olduğu anlașılmaktadır. Her yöntemde en düșük RMSE ve MAE değerlerine sahip olduklarından 0-30 cm için bu iki yöntemden biri tercih edilebilir. Bunula birlikte 30-60 ve $60-90 \mathrm{~cm}$ derinlikler için ise SK yönteminin en doğru sonucu veren yöntem olduğu belirlenmiștir.

Çizelge 3. Elektriksel iletkenlik için enterpolasyon yöntemlerinin karșılaștırılması

Table 3. Comparison of interpolation methods for electrical conductivity

\begin{tabular}{|c|c|c|c|c|c|c|}
\hline & \multicolumn{2}{|c|}{$0-30 \mathrm{~cm}$} & \multicolumn{2}{|c|}{$30-60 \mathrm{~cm}$} & \multicolumn{2}{|c|}{$60-90 \mathrm{~cm}$} \\
\hline & RMSE & MAE & RMSE & MAE & RMSE & MAE \\
\hline \multicolumn{7}{|c|}{ DETERMINISTIK YÖNTEMLER } \\
\hline IDWI & 10.502 & 5.072 & 8.697 & 4.610 & 9.155 & 5.316 \\
\hline IDW2 & 11.139 & 4.904 & 9.448 & 4.792 & 9.867 & 5.443 \\
\hline IDW3 & 12.135 & 5.026 & 10.379 & 5.060 & 10.717 & 5.732 \\
\hline IDW4 & 12.849 & 5.191 & 11.015 & 5.265 & 11.015 & 5.265 \\
\hline IDW5 & 13.303 & 5.266 & 11.404 & 5.385 & 11.700 & 6.081 \\
\hline RBF-CRS & 10.632 & 5.000 & 8.871 & 4.626 & 9.347 & 5.323 \\
\hline RBF-ST & 10.551 & 4.932 & 8.740 & 4.805 & 9.166 & 5.626 \\
\hline RBF-M & 11.918 & 4.932 & 10.144 & 4.805 & 10.645 & 5.626 \\
\hline RBF-IM & 10.607 & 5.035 & 8.827 & 4.622 & 9.298 & 5.327 \\
\hline RBF-TPS & 14.494 & 6.283 & 12.390 & 5.919 & 12.288 & 6.570 \\
\hline \multicolumn{7}{|c|}{ STOKASTIK YÖNTEMLER } \\
\hline OK & 11.005 & 4.323 & 9.027 & 4.269 & 9.490 & 5.002 \\
\hline SK & 11.031 & 4.321 & 9.012 & 4.274 & 9.448 & 5.002 \\
\hline UK & 11.005 & 4.323 & 9.027 & 4.269 & 9.490 & 5.002 \\
\hline
\end{tabular}

RMSE: Ortalama Hata Kareleri Toplamının Karekökü, MAE: Ortalama Mutlak Hata
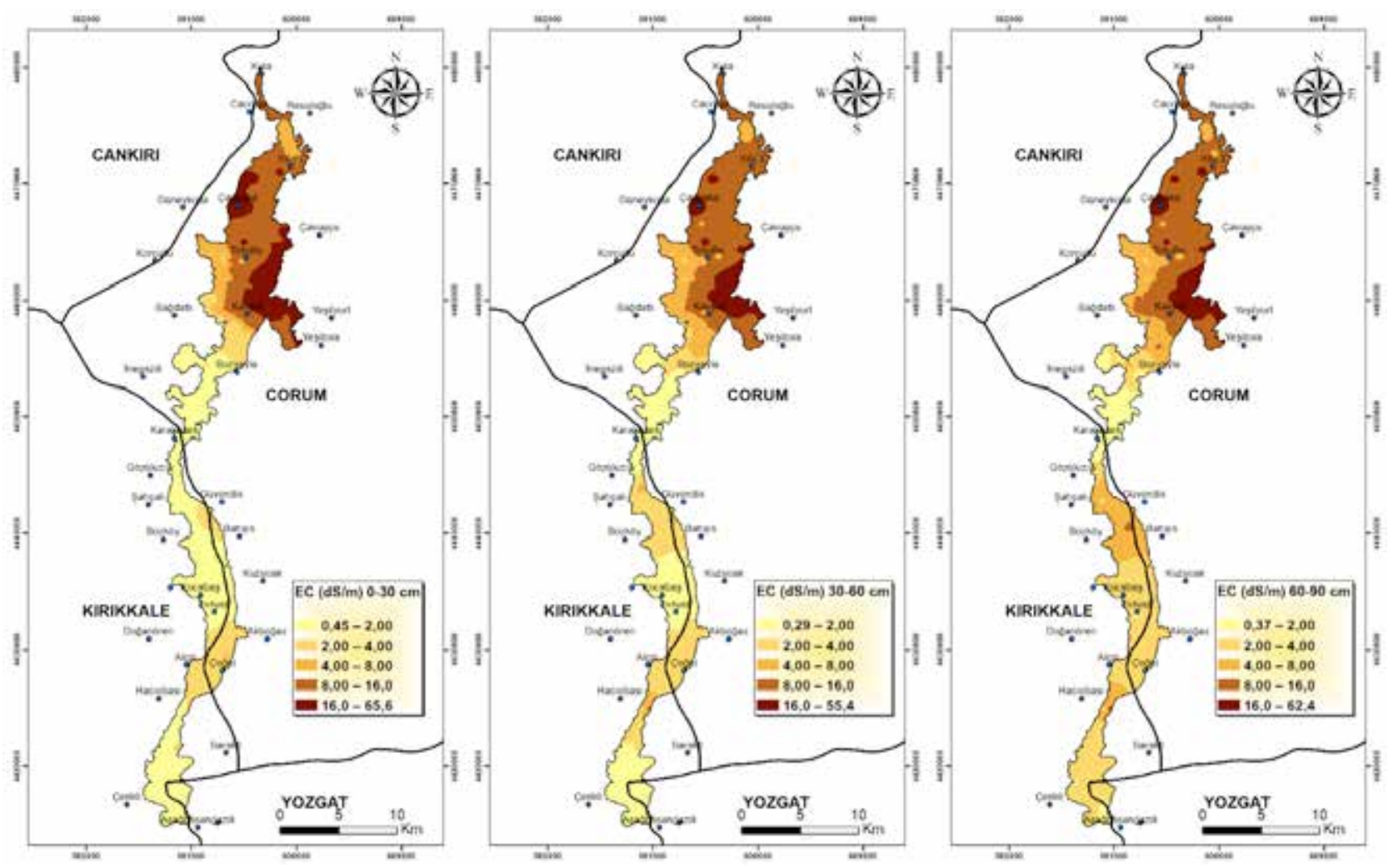

Șekil 2. Çalıșma alanında elektriksel iletkenlik değerlerinin alansal dağıımı

Figure 2. Spatial Distribution of electrical conductivity values in study area 
Çorum ilinin kuzey kesimlerinde yer alan arazilerin önemli bir bölümünde EC değerlerinin her üç toprak derinliğinde de $8.0 \mathrm{dS} \mathrm{m}^{-1}$ den daha yüksek olduğu görülmektedir (Șekil 2). Yağıșlı ve sulama yapılan dönemlerde toprak profilinin alt kesimlerine hareket eden tuzların kuru dönemin sonunda tekrardan toprak profilinin üst kısımlarına doğru hareket etmiș olduğu görülmektedir.

\section{Değișebilir Sodyum Yüzdesi (ESP) Değerlerinin alansal dağııımları}

Tüm deterministik enterpolasyon yöntemleri karșılaștıııldığında ESP değerlerinin

Çizelge 4. Değișebilir sodyum yüzdesi değerleri için enterpolasyon yöntemlerinin karșılaștırılması

Table 4. Comparison of interpolation methods for exchangeable sodium percentage values

\begin{tabular}{ccccccc}
\hline & \multicolumn{2}{c}{$0-30 \mathrm{~cm}$} & \multicolumn{2}{c}{$30-60 \mathrm{~cm}$} & \multicolumn{2}{c}{$60-90 \mathrm{~cm}$} \\
\hline & RMSE & MAE & \multicolumn{2}{c}{ RMSE } & MAE & \multicolumn{2}{c}{ RMSE } \\
\hline IDW1 & 7.790 & 5.169 & 9.736 & 6.289 & 10.714 & 8.074 \\
IDW2 & 7.752 & 5.045 & 9.736 & 6.289 & 11.234 & 8.244 \\
IDW3 & 7.969 & 5.074 & 10.338 & 6.700 & 11.807 & 8.662 \\
IDW4 & 8.212 & 5.165 & 10.888 & 7.008 & 11.807 & 8.662 \\
IDW5 & 8.377 & 5.230 & 11.315 & 7.210 & 12.669 & 9.243 \\
RBF-CRS & 7.752 & 5.093 & 9.384 & 6.014 & 10.667 & 7.936 \\
RBF-ST & 7.604 & 5.139 & 9.117 & 6.711 & 10.571 & 8.376 \\
RBF-M & 8.231 & 5.139 & 10.681 & 6.711 & 11.606 & 8.376 \\
RBF-IM & 7.753 & 5.090 & 9.339 & 5.997 & 10.635 & 7.937 \\
RBF-TPS & 9.602 & 5.503 & 13.416 & 8.550 & 13.909 & 10.444 \\
\hline & & \multicolumn{5}{c}{ STOKASTIK YÖNTEMLER } \\
\hline OK & 7.814 & 4.921 & 9.495 & 5.888 & 11.191 & 8.220 \\
SK & 7.760 & 4.934 & 9.402 & 5.876 & 11.099 & 8.184 \\
UK & 7.814 & 4.921 & 9.495 & 5.888 & 11.191 & 8.220 \\
\hline
\end{tabular}

RMSE: Ortalama Hata Kareleri Toplamının Karekökü, MAE: Ortalama Mutlak Hata
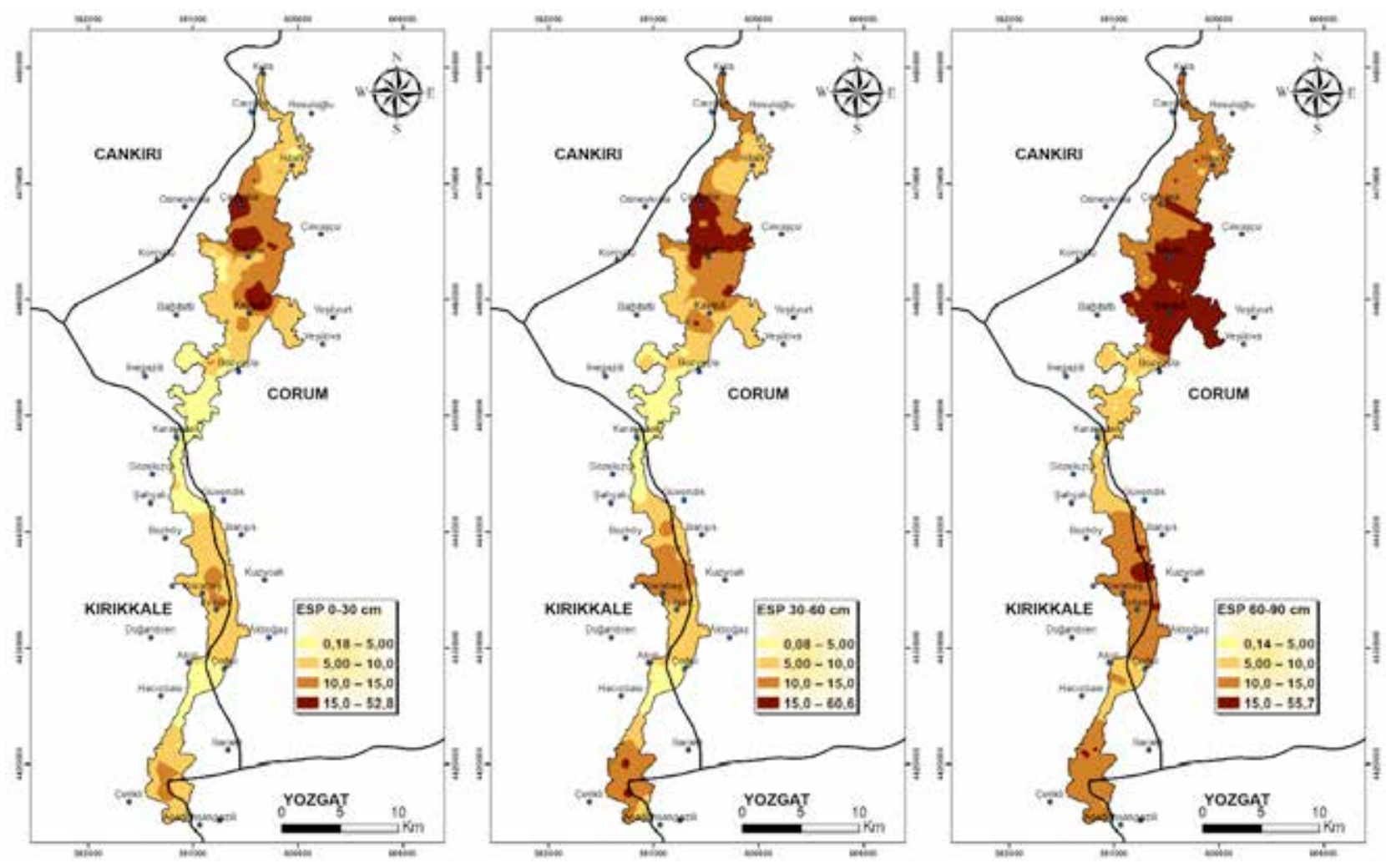

Șekil 3. Değișebilir sodyum yüzdesi (ESP) değerlerine ait alansal dağılım haritaları

Figure 3. Spatial Distribution of exchangeable sodium percentage values in study area 
alansal dağıımlarında $0-30, \quad 30-60$ ve 60$90 \mathrm{~cm}$ derinlikler için RBF-ST yönteminin en doğru sonuç verdiği belirlenmiștir. Stokastik enterpolasyon yöntemlerinin karșilaștırılmasında ise her üç örnekleme derinliğindeki toprakların ESP değerlerinin alansal dağılımlarının en doğru tahmininin SK yönteminin kullanımı ile bașarılabileceği görülmüștür (Çizelge 4).

Çalıșma alanında özellikle Çankırı ilinin güneyi ve Corum ilinin kuzeyi arasında kalan arazilerin önemli bir kısmında her üç toprak derinliğinde de önemli düzeyde alkalilik (sodiklik) sorunu olduğu anlașılmaktadır. Bununla birlikte, elde edilen haritalarda da derinlikle birlikte ESP değerlerinin artmıș olduğu açık bir șekilde izlenmektedir (Șekil 3).

\section{pH değerlerinin alansal dağıımları}

Araștırmaya konu olan tüm deterministik enterpolasyon yöntemler karșılaștırıldığında $\mathrm{pH}$ değerlerinin alansal dağılımları için 0-30 cm toprak derinliğinde IDW-1, 30-60 cm toprak derinliğinde RBF-ST ve $60-90 \mathrm{~cm}$ toprak derinliğinde ise RBF-IM yönteminin en doğru sonuç verdiği belirlenmiștir. Stokastik enterpolasyon yöntemlerinin karșılaștırılmasında ise her üç derinlikteki toprakların $\mathrm{pH}$ değerlerinin alansal dağılımlarının haritalanmasında kullanılabilecek en uygun yöntemin en düșük RMSE değerlerine sahip olan SK yöntemi olduğu görülmektedir.

Toprak pH'sı, toprakta asitlik veya alkaliliğin bir göstergesi olarak kabul edilir ve toprak sağlığının önemli bir göstergesidir. Arazide yetiștirilen ürünün verimini, arazinin ürüne olan uygunluğunu, besin elementlerinin yarayıșıılığını ve toprakta gerçekleșen birçok önemli olayda etkili olan toprak mikroorganizmalarının aktivitelerini etkilemektedir. Birçok bitkinin gelișimi için en uygun $\mathrm{pH}$ aralığı 6.0-7.5 olduğu belirtilmektedir (Simith ve Doran, 1996). Yüzey topraklarında $\mathrm{pH}$ değerleri Kırıkkale ilinin güney ve kuzeyi ile Corum ilinin kuzeyinde bir kısım arazilerde 8.40-8.74 arasında iken, çalıșma alanının geri kalan kısımlarında 8.40'ın altında olduğu görülmüștür (Șekil 4). Yüzey altında 30-60 $\mathrm{cm}$ derinlikte ise Çankırı ilinin kuzeyinde bulunan çalıșma alanının sınırlarına yakın bölgelerde 7.50'nin altında olan $\mathrm{pH}$ değerlerinin alanın büyük bir bölümünde 8.10 ile 8.40 arasında değișmektedir. Bu derinlikte sadece Çorum ilinin kuzey batısında yer alan Bozyayla yerleșim yerine ait bir kısım arazilerde 8.40-8.74 arasındadır. Üçüncü örnekleme derinliği olan $60-90$ cm'de pH değișimi 30-60 cm derinlik ile büyük ölçüde benzerlik göstermektedir.

Çizelge 5. $\mathrm{pH}$ değerleri için enterpolasyon yöntemlerinin karșılaștırılması

Table 5. Comparison of interpolation methods for $\mathrm{pH}$ values

\begin{tabular}{|c|c|c|c|c|c|c|}
\hline \multirow[t]{2}{*}{ Yöntemler } & \multicolumn{2}{|c|}{$0-30 \mathrm{~cm}$} & \multicolumn{2}{|c|}{$30-60 \mathrm{~cm}$} & \multicolumn{2}{|c|}{$60-90 \mathrm{~cm}$} \\
\hline & RMSE & MAE & RMSE & MAE & RMSE & MAE \\
\hline \multicolumn{7}{|c|}{ DETERMINISTIK YÖNTEMLER } \\
\hline $\mid D W 1$ & 0.459 & 0.377 & 0.471 & 0.389 & 0.448 & 0.374 \\
\hline IDW2 & 0.481 & 0.398 & 0.515 & 0.409 & 0.479 & 0.395 \\
\hline IDW3 & 0.508 & 0.416 & 0.548 & 0.429 & 0.514 & 0.415 \\
\hline IDW4 & 0.508 & 0.416 & 0.570 & 0.444 & 0.538 & 0.428 \\
\hline IDW5 & 0.541 & 0.437 & 0.584 & 0.454 & 0.554 & 0.439 \\
\hline RBF-CRS & 0.462 & 0.383 & 0.479 & 0.390 & 0.445 & 0.369 \\
\hline RBF-ST & 0.464 & 0.420 & 0.455 & 0.439 & 0.448 & 0.409 \\
\hline RBF-M & 0.506 & 0.420 & 0.560 & 0.439 & 0.501 & 0.409 \\
\hline RBF-IM & 0.460 & 0.380 & 0.475 & 0.388 & 0.444 & 0.370 \\
\hline RBF-TPS & 0.597 & 0.496 & 0.681 & 0.535 & 0.573 & 0.472 \\
\hline \multicolumn{7}{|c|}{ STOKASTIK YÖNTEMLER } \\
\hline OK & 0.472 & 0.393 & 0.517 & 0.412 & 0.481 & 0.390 \\
\hline SK & 0.467 & 0.385 & 0.510 & 0.411 & 0.474 & 0.381 \\
\hline UK & 0.472 & 0.393 & 0.517 & 0.412 & 0.481 & 0.390 \\
\hline
\end{tabular}

RMSE: Ortalama Hata Kareleri Toplamının Karekökü, MAE: Ortalama Mutlak Hata 


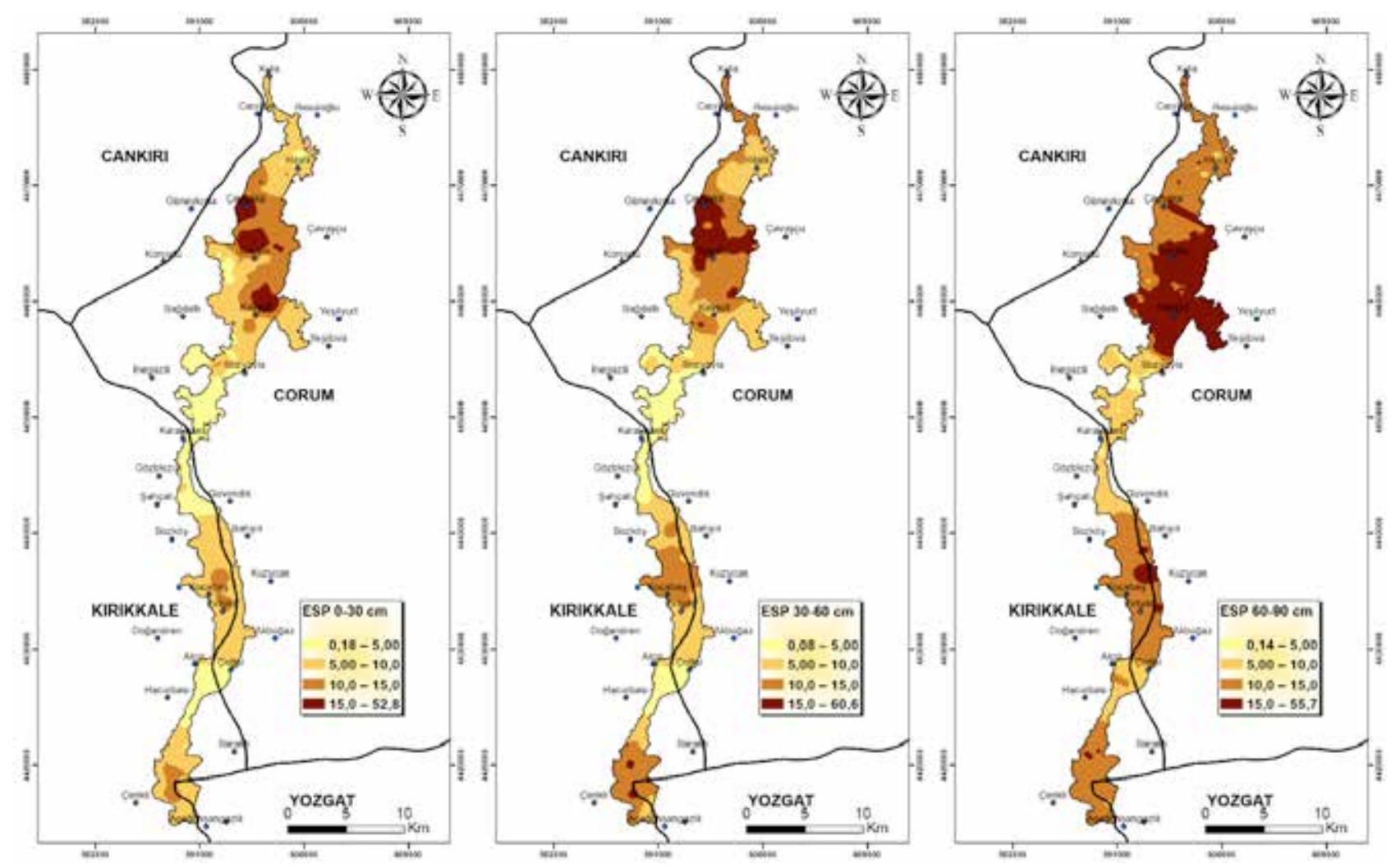

Șekil 4. Toprak pH'sına ait alansal dağılım haritaları

Figure 4. Spatial Distribution of $\mathrm{pH}$ values in study area

\section{SONUCLAR}

Bu çalıșmada, Çankırr ilinin kuzeyindeyer alan Kula Köyüile Yozgat ilinin batısındaki Așağiihsangazili Köyü arasında Delice Çayının etrafındaki DSi'nin Gelingüllü Cerikli Sulama sahasında yer alan arazilerin tuzluluk ve sodiklik durumunun alansal dağılımı modellenmiș ve en uygun enterpolasyon yönteminin belirlenmesi ile haritalanmıștır. Örnekleme yapılmayan noktaların elektriksel iletkenlik (EC), değișebilir sodyum yüzdesi (ESP) ve $\mathrm{pH}$ değerlerinin tahmininde 3 stokastik ve
2 deterministik yöntemden yararlanıımıștır. Her bir deterministik yöntem altında da 5 farkı fonksiyona ait enterpolasyonların doğrulukları test edilmiștir. Böylelikle her bir özelliğin farklı derinliklerinin alansal dağılımlarının modellenmesinde deterministik ve stokastik toplam 13 enterpolasyon yönteminin doğruluğu test edilmiș ve en doğru tahmini yapmamızı sağlayan yöntemler seçilmiștir (Çizelge 6).

Çizelge 6. Değișebilir sodyum yüzdesi değerleri için enterpolasyon yöntemlerinin karșılaștırılması

Table 6. Comparison of interpolation methods for exchangeable sodium percentage values

\begin{tabular}{|c|c|c|c|c|c|c|c|}
\hline Derinlik & Dönem & EC & ESP & $\mathrm{pH}$ & EC & ESP & $\mathrm{pH}$ \\
\hline & \multicolumn{5}{|c|}{ DETERMINISTIK } & \multicolumn{2}{|c|}{ STOKASTIK } \\
\hline \multirow{3}{*}{$0-30 \mathrm{~cm}$} & 2005 & RBF-ST & RBF-IM & RBF-IM & OK, SK & SK & SK \\
\hline & 2016 Nisan & RBF-IM & RBF-IM & RBF-IM & SK & OK & SK \\
\hline & 2016 Eylül & IDW-1 & RBF-ST & IDW-1 & UK, OK & SK & SK \\
\hline \multirow{3}{*}{$30-60 \mathrm{~cm}$} & 2005 & RBF-ST & RBF-IM & RBF-ST & SK & SK & SK \\
\hline & 2016 Nisan & RBF-IM & RBF-IM & RBF-IM & SK & SK & OK \\
\hline & 2016 Eylül & IDW-1 & RBF-ST & RBF-ST & SK & SK & SK \\
\hline \multirow{3}{*}{$60-90 \mathrm{~cm}$} & 2005 & RBF-IM & RBF-CRS & RBF-CRS & SK & SK & UK \\
\hline & 2016 Nisan & RBF-IM & RBF-IM & RBF-IM & SK & SK & SK \\
\hline & 2016 Eylül & IDW-1 & RBF-ST & RBF-IM & SK & SK & SK \\
\hline
\end{tabular}

SK: Simple Kriging: RBF: Radial Base Function; IDW: Ters UzaklIk Yöntemi; ST: Spline with Tension; IM: Inverse Multiquadratic Function; CRS: Completely Regularized Spline 
Sonuçlar, belirlenen özelliklerin alansal dağılımlarının modellenmesinde her 3 örnekleme döneminde de en doğru sonucu veren deterministik ve stokastik enterpolasyon yöntemlerinin farklı olduğunu göstermiștir. EC değerlerinin alansal dağılımında deterministik yöntemlerden IDW-1 yöntemi ile daha doğru tahmin yapılabildiği görülmüștür. Deterministik yöntemler içerisinde RBF-ST, RBF-IM, RBF-CSR ve IDW-1 yöntemlerinin özelliklerin alansal dağıımlarının doğru tahmin edilmesinde kullanılabileceği sonucuna varılmıștır. Ancak bu yöntemlerden RBF-IM'ın diğer yöntemlere kıyasla daha çok tercih edilebileceği düșünülmektedir.

Stokastik enterpolasyon yöntemlerinden SK her üç özellik içinde örneklerin alansal dağılımlarının belirlenmesinde en doğru tahmin yapan yöntem olmuștur. Bu durum, coğrafi bilgi sistemleri kullanılarak yapılan haritalama çalıșmalarında enterpolasyon modeliseçimlerinin nekadarönemli olduğunun anlașılması açısından son derece önemlidir. Zira birçok araștırmacı, kullandıkları programın uygun gördüğü veya programda varsayılan (default) enterpolasyon yöntemini kullanarak örneklenmeyen noktaların tahminlerini yaptırmakta ve ardından bu değerleri kullanarak alansal dağıım haritalarını olușturmaktadırlar. Bu șekilde üretilen haritalarda hata payının yüksek olması elde edilen haritalardan üretilecek faydanın da azalmasına neden olacaktır. Sonuçlar, enterpolasyon yöntemleri kullanılarak olușturulan haritalarda hataya en düșük seviyede tutabilmek için, birden fazla yöntemin denenmesinin ve en doğru tahmin yapılmasına izin veren yöntemin kullanılmasının önemini açık bir șekilde ortaya koymaktadır.

Çalıșma alanı için üretilen tuzluluk, sodiklik ve $\mathrm{pH}$ haritalarında gözlemlenen farklılığın en önemli nedeninin ise toprak örneklemelerinin yapıldığı dönem olduğu düșünülmektedir. Zira kurak bir dönemde yapılan örnekleme ile yağıș ve sulamalardan sonra yapılan örneklemeler arasında özellikle tuz konsantrasyonu açısından önemli farklılıklar olușabilmektedir. Kurak dönemde, tuz ve sodyum konsantrasyonu yüksek olan taban sularının kapilarite ile toprak profilinin üst kısımlarına tașınıyor olması, örnekleme derinliklerinde EC, ESP ve $\mathrm{pH}$ değerlerinin yüksek çıkmasına neden olmuștur. Çalıșilan alanda tuz ve sodiklik ile birlikte yüksek pH'dan kaynaklanan alkalilik sorunlarının olduğu muhakkaktır. Elde edilen haritalar çalıșma alanında sorunların en șiddetli olduğu ve ıslah ișlemlerinde öncelikli alanların nereleri olması gerektiğini de açık bir șekilde göstermektedir. Çankırı ilinin güney ile Corum ilinin kuzeyi arasında kalan bölgede her üç örnekleme döneminde de gözlemlenen tuzlu ve sodik alanlarda alınacak tedbirler ve uygulanacak ıslah programları ile arazilerin ıslah edilmesi ve tarımsal üretimin iyileștirilmesi mümkündür. Bölgede ıslah ile araziden uzaklaștırılacak tuzlu ve iyonlarca yoğun olan suların tahliye edilecek bir drenaj ağının bulunması ise önemli bir avantaj olarak görülmektedir.

\section{TEȘEKKÜR}

Bu çalıșma T.C. Tarım ve Orman Bakanlığı, Araștırma Geliștirme Destek Programları kapsamında TAGEM/TSKAD/15/A13/P08/11 nolu proje ile desteklenmiștir.

\section{KAYNAKLAR}

Bilgili AV (2013). Kriging teknikleri kullanılarak Harran Ovası'ndaki toprak tuzluluğunun mekansal değerlendirmesi. Çevre İzleme vr Değerlendirme, 185:777-795.

Bhunia GS, Shit PK, Maiti R (2018). Comparison of GISbased interpolation methods for spatial distribution of soil organic carbon (SOC). Journal of the Saudi Society of Agricultural Sciences, 17(2):114-126.

Brus DJ, Heuvelink GBM (2007). Optimization of sample patterns for universal kriging of environmental variables. Geoderma:138: 89-95.

Budak M, Günal H (2015). Tuzlu-Alkali Topraklarda Bor Konsantrasyonunun Uzaysal Değișkenliğinin Jeoistatistiksel Analizi ve Haritalanması. Ege Üniversitesi Ziraat Fakültesi Dergisi, 52(2):191-200

Cambardella CA, Moorman TB, Novak JM, Parkin TB, Karlen DL, Turco RF, Konopka AE (1994). Field-Scale Variability Soil Properties in Central lowa Soils. Soil Sci. Society of American Journal, 58:1501-1511.

Cetin M, Kirda, C, 2003. Spatial and Temporal Changes of Soil Salinity in a Cotton Field Irrigated with Low-quality Water. Journal of Hydrology (272):238-249.

Cetin M, Diker K (2003). Assessing Drainage Problem Areas by GIS: A Case Study in the Eastern Mediterranean Region of Turkey. Irrigation and Drainage (52):343-353.

Cetin M (1996). Jeoistatistiksel Yöntem ile Nokta ve Alansal Yağıșların Saptanması ve Stokastik Olarak Modellenmesi Örnek Havza Uygulamaları. C..Ü. Fen Bilimleri Enstitüsü Tarımsal Yapılar ve Sulama Ana Bilim Dalı, Doktora Tezi, Sayfa: 1-127, 6 Temmuz-1996, Adana. 564

Cetin M, Özcan H, Tülücü K (1999). Așağı Seyhan Ovası (ASO) IV. Merhale Proje Alanı Toprak ve Taban Suyuna illișkin Bazı Fiziksel ve Kimyasal Özelliklerin Olasılık Dağılım Fonksiyonlarının Belirlenmesi. GAP I. Tarım Kongresi, Sayfa: 547-554, Harran Üniversitesi Ziraat Fakültesi, 26-28 Mayıs 1999, Sanlıurfa. 
Cetin M, Özcan H, Tülücü K (2001). Așağı Seyhan Ovası (ASO) IV. Merhale Proje Alanında Toprak ve Taban Suyuna İlișkin Bazı Fiziksel ve Kimyasal Özelliklerin Yersel Değișimlerinin Jeoistatistik Yöntemle Araștırılması. Ç. Ü. Rektörlüğü Araștırma Fonu Projesi Sonuç Raporu, 19 sayfa, Proje No: ZF/99/14, Adana.

Citakoğlu H, Cetin M, Cobaner M, Haktanır T (2017). Mevsimsel Yağıșların Jeoistatistiksel Yöntemle Modellenmesi ve Gözlemi Olmayan Noktalarda Tahmin Edilmesi. IMO Teknik Dergi, 28(1): 7725-7745, Ocak 2017. DOI:10.18400/ tekderg.299132.

Emadi M, Baghernejad M (2014). Comparison of spatial interpolation techniques for mapping soil $\mathrm{pH}$ and salinity in agricultural coastal areas, northern Iran. Archives of Agronomy and Soil Science, 60(9):1315-1327.

Jorenush MH, Sepaskhah AR (2003). Modelling capillary rise and soil salinity for shallow saline water table under irrigated and non-irrigated conditions. Agricultural Water Management, 61(2):125-141.

Juan P, Mateu J, Jordan MM, Mataix-Solera J, MeléndezPastor I, Navarro-Pedreño J, (2011). Geostatistical methods to identify and map spatial variations of soil salinity. Journal of Geochemical Exploration, 108(1):62-72.

Isaaks EH, Srivastava RM (1989). An introduction to applied geostatistics. Oxford University Press.

Kis IM (2016). Comparison of Ordinary and Universal Kriging interpolation techniques on a depth variable (a case of linear spatial trend), case study of the Sandrovac Field. Rudarsko-Geolosko-Naftni Zbornik, 31 (2):41-57.

Li J, Heap AD (2008). A review of spatial interpolation methods for environmental scientists.

Li HY, Webster R, Shi Z (2015). Mapping soil salinity in the Yangtze delta: REML and universal kriging (E-BLUP) revisited. Geoderma, 237:71-77.

Mulla DJ, Mc Bratney AB (2000). Soil Spatial Variability. Chapter \#9. In: Sumner M E. (Ed.), Handbooh of Soil Science. CRC Press, pp. 321-352.

Navarro-Pedreño J, Jordan MM, Meléndez-Pastor I, Gómez I, Juan P, Mateu J, (2007). Estimation of soil salinity in semi-arid land using a geostatistical model. Land Degradation and Development 18:339-353.
Nouri H, Chavoshi Borujeni S, Alaghmand S, Anderson S, Sutton P, Parvazian S, Beecham S (2018). Soil Salinity Mapping of Urban Greenery Using Remote Sensing and Proximal Sensing Techniques; The Case of Veale Gardens within the Adelaide Parklands. Sustainability, 10(8):1-14.

Rahmanipour F, Marzaioli R, Bahrami HA, Fereidouni Z, Bandarabadi SR (2014). Assessment of soil quality indices in agricultural lands of Oazvin Province, Iran. Ecological Indicators, 40:19-26.

Rhoades JD (1993). Electrical conductivity methods for measuring and mapping soil salinity. Advances in Agronomy. 49:201-251.

Smith JL, Doran JW (1996). Measurement and Use of $\mathrm{pH}$ and Electrical Conductivity for Soil Quality Analysis. In Methods for Assessing Soil Quality (Vol. 49). Soil Science Society of America Madison, WI.

Surucu A, Ahmed TK, Gunal E, Budak M (2019). Spatial Variability of Some Soil Properties in an Agricultural Field of Halabja City of Sulaimania Governorate, Iraq. Fresenius Environmental Bulletin. 29(1):193-206.

Thomas GW (1982). Exchangeable cations. In: Methods of Soil Analysis. Part II. Chemical and Microbiological Properties, Mad., WI-USA: ASA-SSSA. Pp. 159-165.

Webster R, (2001). Statistics to support soil research and their presentation. European Journal of Soil Science, 52(2):331-340.

Webster R, Oliver MA (2001). Geostatistics for environmental scientists. Brisbane: Wiley.

Wilding LP (1985). Spatial Variability: Its Documentation, Accommodation and Implication to Soil Surveys. In: Nielsen Dr, Bouma J, Editors. Soil Spatial Variability. Wageningen: Pudoc; pp. 166-194.

Wackernagel H (2003). Multivariate Geostatistics: An Introduction with Applications. Springer, Berlin, 387 pp.

Wright G 2003. Radial Basis Function Interpolation: Numerical and Analytical Developments. Ph.D. Thesis, University of Colorado, Boulder. 